\title{
THE SOUTHERN CONTRIBUTION TO REGIONAL SCIENCE
}

\author{
James C. Hite*
}

\section{Introduction}

Two decades ago, in the opening paper of a much-cited book edited by Greenhut and Whitman, Clarence H. Danhof offered an extensive review of the evolution of regional analysis in the South up unto that time. Danhof demonstrated convincingly that at least some of the intellectual roots of regional science could be found in the desire of Southern social scientists to understand their unique region within a national social order. My purpose in this paper is to view the same vista examined by Danhof, but from the perspective of 20 additional years down the road of Southern and intellectual history.

Regional science was still in its infancy at the time Danhof prepared his 1964 review. The Regional Science Association came into existence in 1953, and this Association in 1962. ${ }^{1}$ The early 1960s represent a kind of watershed in regional analysis for that reason, and the Danhof review comes at a particularly opportune time for my purpose in this paper. Did regional science simply take over the body of knowledge pioneered by Southern social scientists in the first half of this century? To what extent has the direction of regional science been influenced by that early work focused on the South? And to what extent, if any, has the direction of work focused on the South been influenced by developments in regional science?

To answer these questions, I will first review the development of regional analysis in the South in the pre-regional science era. I will then examine the influence of that work on the

\footnotetext{
*Alumni Professor of Agricultural Economics and Rural Sociology and Senior Fellow of the Strom Thurmond Institute, Clemson University. Presidential address delivered at 23rd meeting of the Southern Regional Science Association, Washington, D.C., May 10, 1985. Valuable contributions offered by Lowell Ashby, Andrew M. Isserman, William H. Miernyk, James M. Stepp, and Shirley F. Weiss are acknowledged, but all errors remain the responsibility of the author.
}

early literature of regional science. The third order of business is an examination of the nature of Southern regional science in the past 25 years. Finally, I will conclude with an assessment of Southern regional science, both in terms of its contribution to scholarship generally and its current status.

\section{Southern Regional Analysis, 1787-1960}

\section{Development of the Intellectual Base}

Significant work in the South dealing with regional analysis can be traced back at least as far as publication in 1787 of Thomas Jefferson's Notes on the State of Virginia. Indeed, Jefferson's work established a pattern for much of the later regional work in the South. Notes on the State of Virginia is a comprehensive inventory of Virginia's natural and human resources that, while lacking the statistical detail that would be easily possible-and even expected-today, has a just claim as a classic of continuing value.

Almost a century later, Henry Hammond provided a similar inventory for South Carolina, a 725-page, intensely scholarly report issued by the State Board of Agriculture that divided South Carolina into subregions, and examined the state's water resources, population, labor force, government, economy and social institutions. Hammond's report, in the words of Lepawsky, writing in 1948, was a ". . compendium of which any comprehensive planner or social researcher today would be proud" (Lepawsky, p. 7). Indeed, both Jefferson's Notes and Hammond's report anticipated the popularity in the South of elaborate resource inventories undertaken by state planning agencies in the 1930s.

In the years between the appearance of Jefferson's Notes and Hammond's report, there is little issuing forth from the South that would meet today's standards for scientific regional analysis. George Fitzhugh's Sociology for the South, while interesting as a historical document, is psuedo sociology at best, and at worst, a convoluted defense of the institution of slavery more closely akin to Hitler's Mein 
Kampf than to any pioneering work in regional sociology. Its influence on subsequent developments in Southern regional analysis was minimal.

The rationality of Jefferson almost disappeared in the South in the second quarter of the nineteenth century (Hite and Hall). But a Northerner, Thomas Prentice Kettell, provided a rather insightful analysis of the interregional linkages between the Southern and Northern economies in a book published in 1860 entitled, Southern Wealth and Northern Profits. Kittell, like Fitzhugh, provided a defense of slavery, but his was a defense rooted in solid economic analysis that highlighted the interdependence of the Northern and Southern economies in the pre-Civil War period. After the outbreak of Civil War, Kittell's book made him an unpopular person in the North and he died in obscurity in California, his work largely forgotten.

By the end of the nineteenth century, however, a group of bright young Southerners had migrated northward to Baltimore to undertake graduate studies at the new Johns Hopkins University. The attraction at Hopkins was not simply that it was one of the first American universities to offer the Ph.D. and that it was located in a border city not inhospitable to young Southern students. Part of the attraction was presence of a pioneer American scholar in the social sciences, Herbert Baxter Adams.

Adams conducted the graduate seminars at Hopkins along the lines he had been exposed to while a student at the German universities, particularly Berlin and Heidelberg. He had a strong interest in regional institutions, encouraged his Southern students to concentrate on the history of the regional institutions in the South, and was himself author of an influencial study of Jefferson's management of the University of Virginia. It is not simply happenstance that one of Adams' most distinguished pupils was the originator of the frontier thesis of American history, Frederick Jackson Turner (Kraus, p. 302).

Another center that attracted young Southern scholars in the last years of the nineteenth century was at Columbia University. Beginning with appointment in 1876 of the Tennessee native and German-trained scholar, John William Burgess, as Professor of Political Science and Constitutional Law, Columbia started to attract some of the best young minds from the South. Born in 1844, Burgess, like many of his younger Southern students, knew first-hand of Reconstruction, and was profoundly dissatisfied with the prevailing historical interpretation of that period. Together with his former student and colleague, William A. Dunning, Burgess applied German standards for scientific and scholarly investigation to the study of Southern reconstruction. The findings of the Columbia school came to represent the dominant interpretation of Southern history depicted in the most widely used textbooks.

It is also important to recall that these graduate seminars included not just historians, but future economists of note such as John R. Commons and Thorstein Veblen at Hopkins and E.R.A. Seligman and John Bates Clark at Columbia, as well as sociologists such as Franklin H. Giddings, also at Columbia (Odum, 1927).

There is a direct link between these early seminars at Johns Hopkins and Columbia to regional social analysis in the South. The next major figure in the unfolding story is Howard W. Odum, and that link is through Odum. Born in Georgia in 1884, Odum took a bachelor's degree from Emory and a M.A. from the University of Mississippi. His goal was the Ph.D. program run by Burgess at Columbia, but he was unsuccessful initially in obtaining a fellowship. He ended up at Clark University, taking a Ph.D. there in 1909, then moving on to Burgess' program at Columbia for a second Ph.D. in 1910 (For a brief account of Howard W. Odum as a person, see Jocher, et al, pp. i-xiv).

Odum returned South to make his academic career. He taught at the University of Georgia for a few years, moved to Emory as Dean of Liberal Arts, and in 1920, began his long and productive association with the University of North Carolina as Kenan Professor of Sociology. There, in association with his former student, Rupert B. Vance, and the political scientist, V. O. Key, Odum became the presiding elder of Southern regional studies. From their professorial chairs at Chapel Hill, Odum, Vance and Key set the themes of discussion at all the major academies of the South from the 1920 s well into the 1950 s.

\section{Development of Southern Regionalism}

By the time that Franklin Roosevelt's New 
Deal had been established in Washington, a small trickle of scholary work focused on the South had begun to emerge from social scientists in the region. In 1930, Heer published a study of income and wages in the South, and in the same year, Broadus and George Mitchell came out with a study of Southern industrialization. Serious labor unrest in the South in the 1920s stimulated interest in industrial labor problems in the region, and George Starnes at the University of Virginia and Frank deVyver at Duke published in 1930 a survey of wage and living conditions of workers in major Southern industries.

The work in the 1930s was a collaborative effort involving both economists and sociologists. But it must be conceded that the sociologists, under the leadership of Odum, were first into the field, and with the first issue of Odum's journal, Social Forces, in November, 1922, the first to offer a publication outlet within the region for papers on regional topics. While most of the material published in Social Forces was contributed by sociologists, economists and others also used the journal to publish their work. The Southern Economic Jour nal first appeared in October, 1933, and gradually it took over as the outlet for the work of economists, establishing itself (together with Land Economics,) as perhaps the major place to publish papers focused on regional analysis. The first paper in the first issue of the $S E J$ is a discussion by Tipton Snavely of the possibilities for applying economic analysis in formulation of economic development policy for the South. (It is worthwhile to note that the $S E J$ was the place where Locsh's work was first published in English.)

The sociologists were particularly interested in migration. Two papers published in Social Forces in the 1930s are of particular note: A study by C. Horace Hamilton, a rural sociologist at North Carolina State College, on ruralurban migration in the Tennessee Valley, and Wilson Gee's classic study of differential outmigration from the South. (For other 1930s era work on population and migration in the South, see Geisert; Goodrich; Spengler.) Indeed, both Hamilton and Gee represent the emergence of institutionalized rural sociology within the land-grant colleges of the South, a development that spawned a growing body of empirical studies on migration. Gee, who presided with an iron first over the graduate pro- gram in rural social studies at the University of Virginia, trained many of these rural sociologists and deserves mention beside Odum for bringing sociology to the South. Another pioneering Southern rural sociologist was B. O. Williams. Working first at Clemson and then at the University of Georgia, Williams was one of the co-founders of the Rural Sociological Association and a contributor to the migration studies whose work was cited widely well into the $1950 \mathrm{~s}$.

At least two pieces of work from the South appearing in the 1930 s fit neatly into the framework of regional science as we know it today. The earliest (1933) was a study of farm trade centers in Louisiana by T. Lynn Smith, a precursor of the later work of Greenhut and regional scientists interested in location studies. The other was a study of income at the county level in Alabama, published in 1939 by W. M. Adamson of the University of Alabama. Adamson's work anticipated by almost 20 years the interest in small area income estimates that came to the forefront in the 1950 s.

The major works of the 1930 s were offered by Howard Odum and Rupert Vance. It is difficult today to understand the reception that Odum's Southern Regions of the U.S. received when it was published in 1936. It went through four printings (Jocher, et al, pp. xi-x), was widely used in courses and seminars at major universities all across the country, and was a catalyst for the famous New Deal concern with the South as the Nation's Economic Problem Number One (Danhof, in Greenhut and Whitman, p. 32). Even as late as the 1950s, Southern Regions was called "the most definitive study of cultural regions in contemporary society ..." (Nelson, p. 39). The book established Odum was the Walter Isard of the 1930s.

The statistical techniques used in Southern Regions were, for their time, quite sophisticated. Odum used factor analysis on more than 700 physical, economic, and social variables to classify regions, and was the first to make use of such an approach. That approach has proven his legacy to geographers and regional scientists (Reed, p. 42). But like so much of the better work of Southerners, the book is, fundamentally, an exercise in empiricism, and as such, both it and Vance's Human Geography, are firmly in a tradition going back to Jefferson's Notes. Detail is piled upon detail without 
any theory that would allow sorting out of the significant details. As John S. Reed observes, “. . hardly a generalization, and never a hypothesis is to be found" (Reed, p. 57). Today, both Odum's Southern Regions and Vance's Human Geography are badly dated because they failed to provide a conceptual framework for the understanding of regions as social entities. That is also the reason, Professor Reed suggests, why regional sociology, the offspring of Odum, failed to live beyond the life of its founder (Reed, pp. 33-44; see also Heberle).

Outside of academia, the 1930s were, in the words of Albert Lepawsky, the "decade of state planning" (Lepawsky, pp. 8-19). Spurred by the establishment in 1935 of the National Resources Board and the allocation of funds under the PWA program for employment of consultants to state planning agencies, all the Southern states established state planning agencies between 1933 and 1938. The program was nationwide, but the Southern states, conscious of their special regional problems, participated more intensely than the rest of the country. Lepawsky reports that in 1941 , state planning in the Southern states covered an average of 5.5 of the 20 planning fields, while the national average was 4.5 of the 20 fields (Lepawsky, p. 17). In many states, faculty from the universities were used as part of the effort, particularly in designing and conducting extensive resource inventories. Hence the budding interest in regional analysis among scholars was nurtured by the state planning work. In almost every Southern state, the "planning" concept fell into disfavor in the $1940 \mathrm{~s}$, but in almost every state, the old state planning agencies became the nucleus of the modern state development agencies charged with the attraction of industry (Lepawsky, pp. 37-80).

That metamorphosis of the state planning agencies into industrial development agencies provides the background for identifying some major themes in Southern regional analysis during the 1940s and 1950s. At least six major lines of work can be so identified. Detailed analysis of each would make this paper much too long, but a brief description of each seems appropriate:

1) Industrialization as a Strategy for Regional Development, including Empirical Analysis of Location Decisions.
Major contributors on this theme were Bonham, Deming, Dunn; Greenhut and Colberg; Hanna; Herring; Hoover and Ratchford; McFerrin; McLaughlin and Robock; Robock (1954); and van Sickle.

2) Manpower and Wages, including Analysis of Effects of Federal Minimum Wage Legislation on the South. Major contributors include Colberg (1960); Cutler; deVyver; Douty; Fuchs and Perlman; Lester; Markham; Myrdal; Robock and Peterson; Snavely (1947); Sufrin, Swinyard and Stephenson; and Vance.

3) Industrial Subsidies, including Tax Breaks and Use of Municipal Bonds to Finance Industries. A relatively large body of literature developed around this theme. Major contributors include Colberg (1960); Cutler; deVyver and Rinehart.

4) Freight-Rate Problems. Concern over apparently discriminating freight rates spawned significant work by Heath; Joubert; Kline; and Stocking.

5) Migration. Following up on a theme evident even in the 1930s, a body of literature on migration from the South grew rapidly in the 1940s and 1950s. Major contributions include work by Folger; Harrison; Maddox (1960); Spengler; and van Sickle (1946).

6) Agricultural Productivity and Rural Industrialization. This theme emerged out of the problems of low productivity in Southern agriculture and the need to find alternative employment for underemployed farm workers. Major contributors were Aull; Baum and Heady; Demmon; Fulmer; McElveen and Bachman; Nicholls; Robock (1952); Ruttan; Starnes, Wilkins and Wiseman; Stepp; Street; Tang; and van Sickle (1942).

Perhaps the most important coordinated body of work on regional problems undertaken in the postwar South was that sponsored by the Committee of the South of the National Planning Association. Professor Calvin B. Hoover of Duke was the research director for this work which culminated in a book he coauthored with B. U. Ratchford, entitled, Economic Resources and Policies of the South, published in 1951. But the work sponsored by 
the Committee of the South also resulted in publications by McLaughlin and Robock on industrial location decisions, by Deming on disposal of surplus war plants in the South, by Lepawsky on state planning and development programs in the region, and by Stepp on rural industrialization. For two or more decades after these reports appeared, it was difficult to find any serious study of the South that fails to cite at least some of the literature resulting from the work sponsored by the Committee of the South.

The Hoover and Ratchford book deserves special attention. While some of the empirical data are now out-of-date, the book remains, even today, perhaps the finest work on the South ever produced by social scientists. Rich in empirical detail, it is in the tradition of Jefferson's Notes and Hammond's Report, but it goes beyond a mere inventory to provide a disciplined scientific analysis of the policy options for Southern development.

Danhof observes that the Hoover and Ratchford book, together with the other reports issued by the Committee of the South upon which Hoover and Ratchford drew,

... marks a turning point in the analysis of Southern economic problems. Each of the issues which had agitated earlier writers ... was examined ... many were pushed aside as superficial, as unimportant, or as having no causal significance. The fundamental position taken was that Southern economic growth was dependent upon a national economy operating at high levels of employment (Danhof, in Greenhut and Whitman, p. 55).

In offering such a conclusion, Hoover and Ratchford tended to set to rest the older notions that the South was poor because of exploitation by Northern monopoly capital. The South was poor, Hoover and Ratchford argued convincingly, because it had too many people relative to its resources and capital, and it would overcome its poverty only by bringing that ratio of labor to capital into a more favorable balance. That argument soon became the conventional wisdom, replacing, with all except some historians, the relatively unsophisticated notion of the South as a "colonial" region that had been popularized by the work of Odum.

Indeed, increasingly in the $1950 \mathrm{~s}$, a dialectic tension is observable in Southern regional analysis. Arising to challenge the ideas and approach taken by Odum and his followers were researchers clearly influenced by the logical positivist methodology advocated by Karl Popper. Hoover and Ratchford's book shows the influence of the logical positivists, and that is one of the things that makes the book seem modern even today, 35 years after it was published. In some sense, the Hoover and Ratchford book is a transitional piece, tying the older body of work from the 1930s and 1940 s to the regional science literature that was to come. The work of Professor Rutledge Vining at the University of Virginia on regional aspects of business cycles also belongs to this transitional literature, as does much of the work of Edgar Dunn and Marshall Colberg, and the earlier work of Melvin Greenhut.

But the more traditional approach to regional analysis did not pass quietly from the scene. In 1960, Professor William Nicholls of Vanderbilt published a book-length expansion of his 1959 Presidential Address to the Southern Economic Association. Entitled Southern Traditional and Regional Progress, Nicholls' book was greeted with considerable acclaim as well as very biting criticism. His thesis was that Southern progress was impeded by a set of regional traditions out-ofphase with modern industrial capitalism. In some ways, Nicholls' book could only have been written by someone who had been immersed in the agrarian myths that the Vanderbilt Fugitives so eloquently celebrated (Twelve Southerners).

To Nicholls' critics, the problem was that many of the Southern traditions scrutinized by Nicholls existed more in the romantic imaginations of the intellectuals at Vanderbilt than in the reality of Southern society. Still, Nicholls was a first-rate economist with an established reputation in agricultural economics where he pioneered work on the structure of agricultural markets (his father was the longtime head of the agricultural economics department at the University of Kentucky). He had also done important, technically-sophisticated work on industrialization in the East Tennessee Valley, one of the first areas of the South to develop a substantial manufacturing base. If one accepts the traditions examined by Nicholls as valid (and there is at least a semblance of validity in some of them), Nicholls' book is a highly per- 
ceptive work in the tradition of institutional economics. It owes as much to Thorstein Veblen as to Howard Odum and V. O. Key, but it must be seen as the brilliant culmination of the regionalist school of analysis stemming from Odum and his colleagues at Chapel Hill.

\section{The South and the Origins of Regional Science}

\section{Influence on Isard}

The foregoing discussion is meant to establish that a significant body of interdisciplinary work on regional analysis developed in the South prior to the appearance of the term, "regional science." While no universally accepted rubric emerged under which that work was classified, the term used by Odum, "regionalism," is an acceptable one (even considering the normativist connotations usually associated with the -ism suffix). It attracted the attention of leading scholars in the region working in history, sociology, economics, and (to a lesser degree) political science, and achieved a remarkable fussion of those disciplines in ways that still eludes regional science. Still, it would be over-reaching to suggest that regionalism laid any claim to be a separate discipline apart from the various social sciences that contributed to it.

Even the most chauvinistic Southerner must concede that the concept of regional science as a separate discipline originated not in the South, but with a native Philadelphian, Walter Isard. The idea must have had roots in Isard's work at Harvard in the late 1940s in development of interregional input-output models (Isard, 1951). It took on institutional form with the formation of the Regional Science Association in 1955, and received its first basic text with the publication of Isard's Methods of Regional Analysis (MRA) in 1960.

Examination of the references contained in the MRA provides a useful starting place to begin seeking out the contribution of the regionalism in the South to infant regional science. There are a total of 1011 references listed at the end of the 11 chapters in the MRA, but some references are listed for two or more chapters (the double-counting is no problem for us here). Before attempting to determine how many of those references might be credited toward a Southern contribution, one must first settle on a definition of "Southern."
For purposes of this paper, it seems reasonable to include among the Southern contribution to the MRA all those works that were authored by native Southern scholars or scholars who spent a significant portion of their careers in association with a Southern institution. It is not a simple task, however, to identify such authors. Many are sufficiently well-known that they can be classified quickly as "Southern" or "non-Southern." Some, however, who spent part, but not all, of their careers at Southern institutions, fall into a gray area that makes them difficult to classify. Others, whose names are not familiar today, can be classified only if one has access to biographical data. In addition to "Southern authors," an argument can be made for including all references in the MRA to works dealing clearly with Southern topics, or published through Southern outlets such as Odum's journal Social Forces, the Southern Economic Journal or by Southern university presses.

Based on such a definition of "Southern," a count was made of the Southern entries in the references listed at the end of each chapter in the MRA. The results of that count are presented in Table 1. Those results show that 86 of the 1011 references included by Isard-8.51 percent-have some known relationship to the South. Given the body of regionalist work upon which Isard\& might have drawn for references, the fact that the South accounted for less than 10 percent of Isard's references is enough to raise some questions about the linkages between the work of the regionists and the work that Isard viewed as fitting his conception of regional science.

The detailed, chapter-by-chapter breakdown of the contributions to the MRA reference list gives some idea of the nature of Southern work that caught Isard's eye. Indeed, of the 79 references associated with the chapter on regional income and social accounts, the South accounts for almost one-third. Many of the works cited are state-sponsored county income estimates (Adamson, 1939; Ashby and Truex; Baugh and Jones; Copeland; Corry; Fisher; Gilliam; Lancaster; McKinney; Myers, Johnson and Martin; L. Thompson) or similar income estimates for larger areas (Cumberland, 1955). Isard seemed especially aware of the work of the Bureau of Population and Economic Research at the University of Virginia since a disproportionate number of 
Table 1

Southern Material References in Methods of Regional Analysis.

\begin{tabular}{|c|c|c|c|}
\hline $\begin{array}{l}\text { Chapter } \\
\text { Title }\end{array}$ & $\begin{array}{c}\text { Total } \\
\text { References }\end{array}$ & $\begin{array}{l}\text { Southern } \\
\text { References }\end{array}$ & Percent \\
\hline Population Projections & 360 & 17 & $4.72^{\circ}$ \\
\hline Migration Estimates & 177 & 14 & 7.91 \\
\hline Regional Income Estimation & & & \\
\hline and Social Accounts & 79 & 25 & 31.65 \\
\hline Interregional Flow Analysis \& & & & \\
\hline Balance of Payments Statements & 67 & 5 & 7.46 \\
\hline Regional Cycle \& Multiplier & & & \\
\hline Analysis & 77 & 7 & 9.09 \\
\hline Industrial Location Analysis \& & & & \\
\hline Related Measures & 69 & 7 & 10.14 \\
\hline Interregional \& Regional & & & \\
\hline Input-Output Techniques & 56 & 4 & 7.14 \\
\hline Industrial Complex Analysis & 7 & 1 & 14.29 \\
\hline Interregional Linear Programming & 30 & 0 & 0 \\
\hline Gravity, Potential \& Spatial & & & \\
\hline Interaction Models & 51 & 3 & 5.88 \\
\hline Channels of Synthesis & 38 & 3 & 7.89 \\
\hline TOTAL & 1011 & 86 & 8.51 \\
\hline
\end{tabular}

the studies he cites were performed under the Bureau's auspices (Copeland; Fisher; Gilliam; Lancaster; L. Thompson).

Several of the other works on income cited by Isard here include papers related to methodology for regional and small-area income estimates (Adamson, 1942; Cumberland, 1956; Fulmer, 1956; J. Martin; W. Thompson). Only one of the Southern references cited on income studies by Isard (Fulmer, 1955) is unambiguously focused on analysis of local income, as opposed to simple, straightforward presentation of the income estimates or presentation of methodology for making such estimates, but Isard might have also drawn upon the work of Heer and Palmer, and did not do so. Southern materials also account for at least 10 percent of Isard's references in two other areas-industrial location analysis and industrial complex analysis. In the latter area, however, the total number of references is the fewest for any chapter in the MRA and the sole Southern work cited is Airov's study of the synthetic fiber industry. In the location chapter, it would hardly have been possible for Isard to have avoided citing the work of Dunn (1952) and Greenhut (1956) without risking the accusation of being unfamiliar with pertinent recent literature, but he overlooked, or consciously decided not to include, the much-cited work of
McLaughlin and Robock, while giving recognition to less well-known papers by Shapiro and W. Thompson (1957).

Indeed, there is a great deal of Southern work in regional analysis published prior to the MRA that Isard either ignored or chose not to include in his references. Odum and Vance each achieve a single citation, but the work of Hoover and Ratchford receives no mention. It is possible that Isard's focus upon "methods" in the MRA explains why much of this work was not included in his references, but much of what was omitted would appear to have as much relevance to methods as some of the work that was cited.

The relatively minor place given the regionalist work in the South by Isard in the MRA might be dismissed as happenstance. But a well-known survey paper by Meyer on regional economics, published in 1963, is even less aware of this Southern work. Only about six percent of the 130 references cited by Meyer can be identified as Southern, a percentage too close to that calculated from the MRA to be dismissed immediately as mere coincidence. Meyer's survey attempts to encompass all of regional economics, and the low representation of Southern work among the references cannot be explained simply by a focus on methods. The hypothesis must be entertained that Isard 
did not look upon the regionalist work as regional science and Meyer did not see it as important regional economics (see Isard, 1956).

\section{Regionalism vs. Regional Science}

We are now in position to answer, at least tentatively, the first two questions posed at the beginning of this paper. To the question, did regional science take over the body of knowledge developed by the Southern regionalists, the answer is almost certainly no. There is much too little of the regionalists' work cited in the early work of Isard to suggest that he was aware of more than a relatively small amount of that work, much too little to have even suggested to him that the new "channels of synthesis," to use the term he employed for the last chapter of the MRA, had already been explored vigorously and with some success in the South for 30 years or more before appearance of the MRA.

Yet there is also too much evidence to ignore that the Southern regionalists' work had some influence on the initial outlines of regional science. The influence of Rutledge Vining's work on regional aspects of business cycles, and perhaps more indirectly, on the concept of regions as economic entities, is apparent, both in the MRA and in some of Isard's other early writing (see Isard, 1942; 1949). Moreover, the fact that almost a third of the references regarding regional income and social accounts cited by Isard are of Southern origins indicates that the work of the Southern regionalists in income estimation for sub-national areas did get taken over and incorporated into regional science.

Yet some of the more significant work of the Southern regionalists apparently played no role in the emergence of regional science. We can only speculate about why not. There seem to be two possible, and not necessarily mutually exclusive, hypotheses: 1) the methodological approach of the Southern regionalists was, by the mid-1950s, not acceptable because it was often not consistent with the dictates of logical positivism; and 2) the Southern regionalists were not so much interested in "regions" as they were interested in "a region,"-i.e., the South.

The first hypothesis has some merit, particularly when one notes that the work of Dunn, Greenhut, and Vining, which Isard does acknowledge, did produce hypotheses subject to empirical refutation. Much of the other work of the regionalists was positivist in the sense that it was highly empirical, notably the work of Odum and Vance, but it did not explicitly produce hypotheses meeting Popper's rigorous standards of falsification, and, hence, arguably was not "scientific." Methodologically, much of the regionalists' work seeks justification in the philosophical pragmatism of Charles Sanders Peirce and John Dewey and is institutionist in character (notably the work of Aull, Gee, Heath, Nicholls, Ratchford, Stepp, Stocking, and van Sickle). A new discipline struggling to be born and recognized as a "science" might have exacerbated its problems in finding acceptance, particularly in the $1950 \mathrm{~s}$ and 1960 s, had it embraced such work that was clearly not in keeping with the requirements of logical positivism.

Still, regionalism had all the hallmarks of an incipient discipline. It had developed a significant body of interlocking literature, cross-citing itself. While it had a narrow, and some might say, provincial focus, it was not intellectually provincial because the principal contributors to the regionalist literature cited and used conceptual work of cosmopolitan sources. I have already noted the reception given to Losch's work in the Southern Economic Journal, and point to acknowledgement of the work of Franz Boas and Lewis Mumford in the work of Odum, and of the work of John Maurice Clark, Edgar Hoover, Simon Kuznets, T. W. Schultz, and A. C. Pigou in the work the principal economists. Both Odum and Vance were elected president of the American Sociological Association; Calvin Hoover, George Stocking, and J. J. Spengler served as presidents of the American Economic Association, and G. H. Aull as president of the American Agricultural Economic Association. Such recognition is seldom given by their peers to academicians of provincial accomplishment. Regionalism may have not become regional science, but it was not because the scholarship of the regionalist left something to be desired.

More plausible is the argument that work of the regionalists lacked cosmopolitan generality. In reviewing the literature produced by the regionalists, one cannot help but be struck by the fact that their interest in regional analysis lay not in purely academic questions. Conscious of the backwardness of the region, 
Southern regionalists felt an almost patriotically compelling need to devote their scholarship to finding remedies for the South's problems. In the South, perhaps more than in any other region, there has been a strong regional identity inherent in the regional analysis (Stepp, 1975). Any focus on theory was subordinated to the pragmatic need to find solutions for real and pressing social problems. That dynamic explains both the tendency toward a methodology rooted in pragmatism and empiricism, and a body of work that, while of extraordinarily high quality, lacked direct relevance to abstract questions related to regions and the space economy, precisely the sort of questions Isard desired that regional science should study.

\section{Southern Regional Science}

Southern Regional Analysis, 1960-1985

We turn now to the last of the three questions: To what extent, if any, has the direction of work focused on the South been influenced by developments in regional science?

That is not the same question as: What has been the Southern contribution to regional science in the past 25 years? But the questions are related, and an answer to the first question is best arrived at by first examining the second.

Harry Richardson's 1978 survey in the International Regional Science Review provides a means of comparing the Southern influence on regional science in 1960 and its influence on at least a part of regional science-specifically regional economics-18 years later. The approach used is essentially the same used to examine the Southern influence on the MRA. Work by Southern authors, work focused upon the South, and work published through Southern outlets cited by Richardson were tabulated. The results are shown in Table 2.

Richardson cites 362 entries. Again, as in the MRA, some titles are cited twice because of the classification scheme used, and so there is some double-counting. But that poses no prob-

Table 2

Southern Materials Referenced in Richardson's Survey.

\begin{tabular}{|c|c|c|c|}
\hline Heading & $\begin{array}{c}\text { Total } \\
\text { References }\end{array}$ & $\begin{array}{c}\text { Southern } \\
\text { References }\end{array}$ & Percent \\
\hline Introduction & 2 & 1 & $50.00^{\circ}$ \\
\hline Meyer's Survey & 9 & 0 & 0 \\
\hline \multicolumn{4}{|l|}{ Theory: } \\
\hline Spatial Price Theory & 16 & 1 & 6.25 \\
\hline Location Theory & 29 & 3 & 10.34 \\
\hline Regional Growth Theory & 20 & 0 & 0 \\
\hline Spatial Diffusion & 12 & 0 & 0 \\
\hline \multicolumn{4}{|l|}{ Methods: } \\
\hline Base Models & 39 & 2 & 6.90 \\
\hline Regional Input-Output & 46 & 14 & 30.43 \\
\hline Econometric Models & 38 & 3 & 7.89 \\
\hline Shift-Share & 40 & 11 & 27.50 \\
\hline Gravity Models & 10 & 0 & 0 \\
\hline \multicolumn{4}{|l|}{ Policy: } \\
\hline Introduction & 21 & 3 & 14.29 \\
\hline Efficiency vs. Equity & 10 & 0 & 0 \\
\hline \multicolumn{4}{|l|}{ Subsidized Migration or } \\
\hline Regional Development & 14 & $\mathbf{0}$ & $\mathbf{0}$ \\
\hline \multicolumn{4}{|l|}{ Capital vs. Labor \& } \\
\hline Infrastructure Subsidies & 5 & 0 & 0 \\
\hline Growth Center Theory \& Policy & 21 & 3 & 14.29 \\
\hline Evaluation of Regional Policy & 15 & 0 & 0 \\
\hline British Experience & 10 & 0 & 0 \\
\hline Conclusions & 5 & 3 & 60.00 \\
\hline TOTAL & 362 & 44 & 12.15 \\
\hline
\end{tabular}


lem for our purposes. Of these entries, 44, or 12.15 percent, qualified as "Southern," compared to the 8.51 percent of the references in the MRA and six percent of the references cited by Meyer (in a survey focused on much the same type of work reviewed by Richardson). The increase in the relative amount of Southern work in the Richardson survey is worthy of note since it indicates that either older Southern work has been discovered by a more general audience, or that Southern work of a more recent vintage has received wider recognition than was the case for the older, regionalist work.

An examination of the dates in the Richardson references will show that, with only a very few exceptions (none relevant to Southern work), all of the titles cited are of a 1960 or later vintage. Hence, it seems reasonable to conclude that Southern regional analysis since 1960 has won marginally wider acceptance than was accorded the earlier work of the regionalist in the pre-regional science era. The possibility remains that what is gaining wider recognition is newer work of the same type as that performed by the regionalist. But the alternative possibility must also be considered that regional science has influenced the qualitative nature of Southern regional analysis in ways that make it more attractive to the international community of scholars.

An examination of the sort of work acknowledged by Richardson will give some clues as to which of those possibilities is the more likely. While Richardson's classification scheme is somewhat different from that of Isard in the MRA, examination of Table 2 shows that Southern work is heavily concentrated in 10 areas, two of which-the introduction and the conclusions-are quite general and contain so few entries as to be of no significance for our purposes. In the area of regional input-output analysis, the South enjoys a position similar to that for income estimation in the MRA, accounting for almost one-third of the citations by Richardson. The South also accounts for almost as large a percentage of the work in shift-share analysis. Indeed, slightly more than two-thirds (68.18 percent) of the Southern work cited by Richardson falls under his broad classification of "Methods." Outside of the "Methods" work, Southern contributions are sparse and heavily influenced by Greenhut and his students, by Dean and Carroll, and by
Latham, all in spatial price and location theory, and by Hansen in growth pole theory and policy. In many of Richardson's classification areas, there is no Southern work at all.

The Richardson survey thus suggests that much of the best-received Southern work of recent vintage has been highly practical work in empirical methods similar to the regional income estimation work cited by Isard in the MRA. Indeed, with the possible exception of the work centered around Melvin Greenhut, all of the Southern work recognized by Richardson can be so described (Ashby, 1968; Floyd; Floyd and Sirmans; Hale, 1971; Herzog and Olsen; Hite and Laurent; Latham, 1976; Miernyk, 1968, 1970, 1976; Morgan and Hackbart; Moriarty; Schaffer; Schaffer and Chu; Weiss and Gooding).

Yet, while the regionalist tradition lives on in Southern scholarship, it is clear that regional science has influenced that tradition. Regional input-output and shift-share analysis have been grafted on to the tradition. Ashby and Dunn (see Dunn, 1959) have some claim on development of shift-share analysis, but neither it nor input-output were tools used by the regionalist and they were both tools developed largely within the framework of regional science. Growth pole theory, usually associated first with the French economist, R. Perroux, has had no more effective analyst than Niles Hansen, and while the concept is at least implicit in the regionalist work on agricultural productivity and rural industrialization as well as in some of van Sickle's work, it was not clearly elaborated by the regionalists.

Still, Richardson's survey, as all such surveys must, misses some Southern work of the last quarter century of signal importance. Some of that work has been published after the 1978 date of the Richardson survey; some before. At the top of that list must be the work of Professor John R. Moroney at Tulane, including ground-breaking efforts to test the Heckscher-Ohlin hypothesis at the regional level (Maroney and Walker). Richardson cites a later work by Maroney (1975) concerning natural resources and regional trade, but for some reason overlooks the pioneering 1966 article in the Journal of Political Economy, reprinted in Needleman (see also Horiba and Kirkpatrick, 1981). Also overlooked by Richardson, but worthy of note are Colberg's 1963 book on hu- 
man capital in the South and Maddox, et al's 1967 book on Southern manpower. A conscious decision by Richardson to exclude urban economics probably explains failure to recognize the contribution of Stuart Chapin and Shirley Weiss in urban dynamics.

Since appearance of Richardson's survey article, the influence of regional science on Southern regional analysis has grown more pronounced. Migration studies, a theme that was often dominant in the regionalist literature, have been carried forward in such work as that of Cebula and his colleagues, and by Serow and his colleagues, but the sophistication of the work reflects new approaches associated with regional science and the methodology of logical postivism (see also Bellante; Bishop; Cahill and Saluja; Gross and Chang; and Horiba and Kirkpatrick, 1983). Also work on industrial subsidies, another theme reverberating from the regionalist past, continues to be heard, sometimes modified by the influences of regional science, as in the work of Arthur H. Thompson, and sometimes unchanged, in clinging to the old historical school, as in the book by James C. Cobb.

Other old themes that continue to receive attention, but with a new degree of sophistication, include the north-south wage differential and industrialization (see Ersenkal and Dillman; Luisa and Dillman; Mulkey and Dillman; Galloway; McGee). And Southerners are unable to shake a fascination with shiftshare analysis (Ireland and Moomaw; Gordon, Hackett, and Mulkey).

Newly emerging themes perhaps show the influence of regional science on Southern regional analysis most clearly. Some of the work of the late Carl Hale (Hale, 1973) and of William R. Latham (1977) on production within a spatial context is work for which there is little, or no, precedent in the earlier regionalist analysis. Similarly, scrutiny of lags in multipliers by Moriarty, Spreen and Mulkey; and Miller and Henry, while hinted at in some earlier work by Pfouts and W. Thompson, is of a new, different order than might have occurred had not regional science developed as it did. Recent work by Burford and Katz on multipliers also follows this theme.

Among other new themes are urban development, as exemplified by important work on urban land economics by such Southern regional economists as Ellison and Roberts and Kau and Lee, and the work on urban cost-of-living differentials by Haworth and Rasmussen. Growing concern about environmental and energy problems is also evident in the work of an active group of regional scientists centered at the Oak Ridge National Laboratory (Bjornstad, Vogt and Stuckwish; Honea), the work of Miernyk and his colleagues at the Regional Research Institute at West Virginia University (Miernyk, 1976), and by other scholars across the region (see Manuel). Cumberland (Cumberland and Herzog) has done important pioneering work modeling economic-environmental linkages affecting the Chesapeake Bay, and a group of agricultural economists have made important contributions in the measurement of non-market environmental amenities (see Bergstrom, Dillman, and Stoll; Batie and Shabman; Brookshire, Eubanks, and Randall).

One rather unexpected new area in which regional science can be shown to have influence is in the study of Southern regional history. As early as 1943, Professor Thomas D. Clark applied the theory of imperfect competition in a historical context to the study of retailing in the South after the Civil War. But rigorous analysis in keeping with the concept of logical positivism came in the 1970 s as a new breed of historian-economists calling themselves cliometricians began applying tools of econometrics to historical studies of the Southern economy (DeCanio; Ransom and Sutch). Taking up on Clark's hint, some of the most interesting work involves application of Greenhut's spatial price theory to credit merchandising in the post-bellum South (Walton). Few of these cliometricians are Southerners by birth, although some are Southern by academic affiliation. Within the history profession, their work is viewed with skepticism, but they would be at home among regional scientists. Their work is made possible largely by the pioneering work in regional history in the South in the first quarter of the twentieth century (Dodd; Phillips), but it revises that earlier history, substantiating the conclusions of Hoover and Ratchford and others that the South's problems resulted not from any conspiracy of exploitation, but from the workings of a market economy in a region with a surplus of labor and a scarcity of capital. 


\section{Current Status of Southern Regional Science}

This review of the record shows that Southern regional science, drawing upon the regionalist heritage, has made a creditable contribution to the development of regional science generally. That conclusion is strengthened by the analysis of Kau and Johnson in 1983 of the contribution to regional science literature by various institutions and scholars. While the University of Pennsylvania dominates the ranking of schools, the University of North Carolina-Chapel Hill ranks second in the number of pages contributed to the regional science journals in the period 1965-1980. Four of the top 10 contributors, and five of the top 25, are Southern institutions (University of Georgia-4th; University of Maryland-7th; University of Alabama-9th; and University of Texas-Austin-11th). While no Southerner appears in the top 10 authors in pages contributed to these journals, five appear in the top 25 (Charles F. Floyd, Niles Hansen, Richard J. Cebula, Randolph C. Martin and Carl W. Hale) (Kau and Johnson).

The Southern contribution to pure theory remains thin. Recent work by Dunn on the development of U.S. urban system (1980), by $\mathbf{M}$. Olsen, applying concepts originating in the public choice theory (a new body of economic theory with strong Southern roots), and by Vining (1984) on performance of economic systems have enriched that contribution. But still Southern theoretical work must be judged deficient.

It is possible that John S. Reed is right in speculating that Southerners are culturally handicapped in theoretical work by the "particularistic" nature of their regional culture. Reed cites a study by Coulter of persons listed in Who's Who in America in support of his speculation. That study showed that the South produces disproportionately large numbers of soldiers, lawyers, politicians, clergymen, athletes and entertainers, but a disproportionately few scholars, business leaders and artists. Musing about why that is so, Reed speculates that it has something to do with a peculiarly Southern cultural trait to dwell on detail and resist the generalizing that is basic to theoretical work (Reed, pp. 45-57).

If that is so, it is both an advantage and a disadvantage to Southern regional science. It has made Southern regional analysis much richer in detail, more sensitive to institutional arrangements, less likely to be led into absurdities by pushing reductionist logic to its extreme. Southern regional science has been able to avoid some of the pitfalls of irrelevance that Miernyk warned us about nine years ago in his Presidential Address to this organization (Miernyk, 1976). And if Reed is right, our cultural predilection may have aided us. Those predilections would lead us to follow in our theoretical work the example of Dunn and Olsen, and behind them, the work of Schumpeter, Schultz, Myrdal, Lewis, Hayek, and Georgescu-Roegen, shying away from the abstruse abstractions of much of the modern work in economic theory toward which mainstream regional science has gravitated, as is exemplified in the work of Arrow and Debreu (see Harris and Nadji).

If we follow such a course, however, we run two risks. Such an approach is not in the mainstream of theoretical work, and for the same reasons I have speculated that much of the early regionalist literature was ignored by Isard, Southern contributions to theory may be ignored as "unscientific." Miernyk quotes Galbraith (who ought to know) that scientific excellence is defined as "... whatever is closest ... to the scholarly tendency of the people who are already there" (Miernyk, p. 9). The second risk is more personal, that because the work, whatever its quality, fails to achieve wide recognition, the scholars doing such work will be passed over when rewards in the form of academic tenure and promotion are distributed. Both risks can be minimized so long as this organization maintains a journal outlet for high quality work that challenges the mainstream, thereby assuring that such work becomes a part of the intellectual traffic in regional science.

\section{Conclusions}

I started this paper with three questions, two of which were answered along the way. The third concerning the impact of regional science on Southern regional analysis can be answered now, and in offering that answer, some observations in the way of a conclusion about the Southern contribution to regional science are possible.

Without question, regional science, as envisioned and nourished by Walter Isard, has in- 
fluenced the direction of regional analysis focused on the South. It has made that analysis sharper, more sophisticated in its methodology, and, hence, better disciplined. At the same time, to an important degree, it has contributed to the driving out of the sociologists, political scientists, historians, and other social scientists who made the earlier regionalist analysis truly interdisciplinary. Some geographers and engineers have joined in regional science, but more than was true 25 years ago (McKinney and Thompson), the field has been left to the regional economists, and it is a poorer field as a result. What has been gained in scientific rigor is to be applauded; what has been lost in hybrid vigor is to be mourned.

Still, it may not be too bold to say that Southern regional science retains more hybrid vigor than regional science generally. It is the offspring of a mating of Walter Isard to stock native to the South that descends from an unrelated line through John William Burgess and Howard Odum and the Southern regionalists.

Like the region that gives this organization its name, Southern regional science is drawn toward the national consensus but is hestitant to become a part of it. While contributing in meaningful ways to the larger body of regional science literature, Southern regional science stands apart, looking with some bemused skepticism at much that appears in the mainstream regional science literature and, so far, successfully resisting the temptation to concentrate exclusively on reductionist theoretical models. Southern regional science is neoKantian in philosophical approach, but shows little tendency to pursue general theory, exhibiting instead marked phenomentalist and instrumentalist epistemological leanings. That means Southern regional science has tended to seek justification for its work not solely within the community of scholars (although failure to gain acceptance there would be serious cause for concern), but also in the use of the work by pragmatic policy-makers.

Perhaps Southern regional science should be characterized as a separate school within regional science, accepting some things and questioning others. It has different priorities than mainstream regional science. It does not reject the logical positivism that is central to the mainstream, but insists that the major premises must be relevant if the hypotheses ar- rived at by deduction are to be worthy of testing.

And perhaps it is in that role, as a distinct separate school offering an alternative to the mainstream, that Southern regional science has made, and can continue to make, its greatest contribution to regional science generally. Southern regional science can speak strongly through scholarship, too sound to be ignored, a cautionary note about the dangers of what the German philospher, Eric Voegelin, calls estrangement from reality in the social sciences, and for the primacy of revelence over theoretical elegance.

Few things are more important to the future of regional science than that such warning be spoken and heard.

\section{FOOTNOTES}

'The first meeting of what was to become the Southern Regional Science Association was held in Chapel Hill on March 17, 1962. Walter Isard, Lowell Ashby, George Hall and Rutledge Vining were scheduled to present papers, but Vining was unable to attend and his scheduled paper was not presented.

${ }^{2} \mathrm{As}$ is generally known, Isard wrote each chapter in the MRA in collaboration with his students. While, in the Preface to the MRA, Isard assumes responsibility for the material, others were involved in assembling the lists of references. Thus the lists of references at the end of each chapter in the MRA reflect material that had come to the attention of either Isard or one of the students involved with a particular chapter.

\section{REFERENCES}

Adamson, W. M. Income in Counties of Alabama, 1929 and 1935. Multilthed Series No. 1, Bureau of Business Research, Univ. of Alabama, University, Ala., 1939.

Adamson, W. M. "Measurement of Income in Small Geographic Areas," Southern Econ. J. 8 (April 1942).

Airov, Joseph. The Location of the Synthetic Fiber Industry: A Study in Regional Analysis. New York, John Wiley, 1956.

Ashby, L. D. "The Shift and Share Analysis: A Reply," Southern Econ. J. 34 (1968), pp. 423-425.

Ashby, Lowell D. and Everett P. Truex. The Estimation of Income Payments to Individuals in North Carolina Counties. School of Bus. Adm., Univ. of North Carolina, Chapel Hill, 1952.

Aull, G. H. "Employment Prospects in Southern Agriculture," Southern Econ. J. 13 (April 1947), pp. 378-385.

Batie, Sandra S., and Leonard A. Shabman. "Estimating the Economic Value of Wetlands: Principles, Methods, and Limitations," Coastal Zone Mgt.J. 10, pp. 255-278.

Baughn, William H., and Gardner M. Jones. Income Payments in Louisiana: Estimate by Parishes, 1947-48. Baton Rouge, Div. of Research, LSU, March, 1952.

Baum, E. L., and E. O. Heady. "Some Effects of Selected Policy Programs on Agricultural Labor Mobility in the South, Southern Econ. J., 25 (Jan. 1959), pp. 327-337.

Bellante, Don. "The North-South Wage Differential and the Migration of Heterogenous Labor," Amer. Econ. Rev. 69 (1979), pp. 166-175.

Bergstrom, J. C., B. L. Dillman, and J. R. Stoll. "Public 
Environmental Amenity Benefits of Private Land: The Case of Prime Agricultural Land." Working Paper, Dept. of Agric. Econ., Texas A\&M Univ., College Station, 1983.

Bishop, C. E. Farm Labor in the United States. New York, Columbia Univ. Press, 1967.

Bjornstad, D. J., D. R. Vogt, and D. N. Stuckwish. "The Regional Economic Impact of Changes in Import Oil Prices," Rev. Reg. Studies. 9 (Fall 1979), pp. 33-49.

Brookshire, David S., Larry S. Eubanks, and Alan Randall. "Estimating Option Prices and Existence Value for Wildlife Resources," Land Econ. 58 (Feb. 1093), pp. 1-15.

Bonham, Harry D. "The Prospect for Heavy Industry in the South," Southern Econ. J. 13 (April 1947), pp. $395-403$.

Burford, Roger L., and Joseph L. Katz. "A Method for Estimation of Input-Output Type Output Multipliers When No Input-Output Model Exists," J. Reg. Sci. 21 (May 1981), pp. 151-161.

Cahill, Edward E., and U. Saluja. "De-Population and Re-Population: A Demographic Analysis of the TurnAround Counties of the South," Rev. Reg. Studies. 5 (Fall, 1975), pp. 1-13.

Chapin, F. Stuart, Jr. and Shirley F. Weiss. Urban Growth Dynamics. New York, John Wiley and Sons, 1962.

Cebula, R. J., and R. K. Vedder. "An Empirical Analysis of Income Expectations and Interstate Migration," Rev. Reg. Studies. 5 (Winter 1975), pp. 19-28.

Clark, T. D. "Historical Aspects of Imperfect Competition in the Southern Retail Trade after 1865," J. Econ. Hist. 3 (1943) pp. 38-57.

Cobb, James C. The Selling of the South-The Southern Crusade for Industrial Development, 1936-1980. Baton Rouge, LSU Press, 1982.

Colberg, Marshall R. Human Capital in Southern Development, 1939-1963. Chapel Hill, Univ. of North Carolina Press, 1965.

Colberg, Marshall. "Minimum Wage Effects on Florida's Economic Development," J. Law \& Econ. 3 (Oct. 1960), pp. 106-117.

Copeland, Lewis C. Methods for Estimating Income Payments in Counties. Charlottesville, Bur. of Pop. \& Econ. Research, Univ. of Virginia, 1952.

Corry, Ormond C. Income Payments to Individuals in Tennessee Counties, 1939, 1947, and 1949-51. Bur. of Bus. \& Econ. Res. Univ. of Tenn., Knoxville, May 1953.

Cumberland, John H. Monthly Income Estimates for Maryland. Washington. The Chesapeake and Potomac Telephone Cos., July 1955.

Cumberland, John H. "Suggested Improvements in Regional Income Accounting," Papers \& Proc. Reg. Sci. Assoc. 2 (1956).

Cumberland, John H., and Henry W. Herzog, Jr. "Economic-Environmental Planning for Water Quality Control in the Cheaspeake Bay Region," Rev. Reg. Studies., 5 (Fall, 1975), pp. 50-69.

Culter, A. T. Labor Legislation in Thirteen Southern States," Southern Econ. J. VII (1941), pp. 297-316.

Dean, R. D., and T. M. Carroll. "Plant Location Under Uncertainty," Land Econ. 53 (1977), pp. 423-444.

DeCanio, S. J. Agriculture in the Postbellum South: The Economics of Production. Cambridge, MIT Press, 1974.

Deming, Frederick L. and Weldon A. Stein. Disposal of Southern War Plants. Washington, Committee of the South, National Planning Assoc. Report No. 2, No date.

Demmon, E. L. "Forests in the Economy of the South," Southern Econ. J. 3 (April 1937), pp. 319-380.

deVyver, F. T. "The Present Status of Lubor Ünions in South, 1948," Southern Econ. J. 16 (June 1949), pp. 1-22.

Dodd, William E. "Contributions of the South to Economic
Thought and Writing to 1865." The South in the Building of the Nation. V, Richmond, Southern Historical Publication Society, 1909.

Dodd, W. E. The Cotton Kingdom. New Haven, Yale Univ. Press, 1919.

Douty, H. M. "Labor in the South," Monthly Labor Rev. LXIII (1946), pp. 481-586.

Dunn, Edgar S., Jr. The Development of the U.S. Urban System: Concepts, Structures, Regional Shifts. Volume 1. Baltimore, The Johns Hopkins Univ. Press, 1980.

Dunn, E. S., Jr. Location of Agricultural Production. Gainesville, Univ. of Florida Press, 1954.

Dunn, Edgar S., Jr. Recent Southern Economic Development as Revealed by the Changing Structure of Employment. Gainesville, Univ. of Florida MonographSocial Sciences No. 14, Spring 1962.

Dunn, Edgar S., Jr. "The Need for a Research Design for Southern Regional Economics Studies," Southern Econ. J. (July 1962),

Dunn, E. S., Jr., "A Statistical and Analytical Technique for Regional Analysis," Annals and Proc. of the Reg. Sci. Assoc. 1959.

Ellison, Richard, and Blaine Roberts. "Residential Land Development Under Uncertainty," J. Reg. Sci. 23 (August 1983), pp. 309-322.

Ersenkal, C. R., and B. L. Dillman. "The Product Cycle and Shifts in the Location of Manufacturing, Reg. Sci. Perspectives. 14 (Feb. 1985)

Fisher, Dorothy H. Income Trends in Virginia for Selected Years, 1939-1951, by Source. Charlottesville, Bur. of Pop. \& Econ. Research, Univ. of Virginia, 1953.

Fitzhugh, George. Sociology for the South, or the Failure of Free Society. (Originally published at Richmond, 1854.) In Harvey Wish, ed. Ante-Bellum Writings of George Fitzhugh and Hinton Rowan Helper on Slavery. New York,

Floyd, Charles F. "Shift and Share Projection Models: A Reformulation," Annals Reg. Sci. 7 (1973), pp. 40-49.

Floyd, Charles F., and C. F. Sirmans. "Shift and Share Projections Revisited," J. Reg. Sci. 13 (1973), pp. 115-120.

Floyd, Joe S. The Effects of Taxation on Industrial Location. Chapel Hill, Univ. of North Carolina Press, 1952.

Folger, John. "Some Aspects of Migration in the Tennessee Valley," Amer. Soc. Rev. 18 (June 1953).

Fuchs, Victor R., and Richard Perlman. "Recent Trends in Southern Wage Differentials," Rev. Econ. \& Stat. 42 (Aug. 1960), pp. 292-300.

Fulmer, John L. Agricultural Progress in the Cotton Belt Since 1920. Chapel Hill, Univ. of North Carolina Press, 1950.

Fulmer, John L. "Regession Methods of Estimating Agricultural Income by Counties," Rev. Econ. \& Stat. 38 (Feb. 1956).

Fulmer, John L. "State Per Capita Income Differentials: 1940 and 1950," Southern Econ. J. 22 (July 1955).

Gallaway, Lowell E. "The North-South Wage Differential," Rev. Econ \& Stat. 45 (1963), pp. 264-272.

Gee, Wilson. "The 'Drag' of Talent Out of the South," Social Forces 15 (March 1937), pp. 343-346.

Geisert, H. L. "The Trend of Interregional Migration of Talent: Southeast, 1899-1936," Social Forces. 18 (Oct. 1939), pp. 41-47.

Gilliam, Sara K. Distribution of Income in Virginia in 1947 Charlottesville, Bur. of Pop. \& Econ. Research, Univ. of Virginia, 1950.

Goodrich, Carter. Migration and Economic Opportunity. Philadelphia, Univ. of Pennsylvania Press, 1936.

Gordon, John R., William B. Hackett, and David Mulkey. "Using the Shift-Share Technique in Economies with Widely Varying Sectoral Growth Rates: Observations and a Suggested Model Modification," Rev. Reg. 
Studies. 10 (Winter 1980), pp. 57-67.

Greenhut, M. L. Microeconomics and the Space Economy. Chicago, Scott, Foresman, 1963.

Greenhut, M. L., Plant Location in Theory and Practice. Chapel Hill, Univ. of North Carolina Press, 1956.

Greenhut, M. L., and M. R. Colberg, Location of Florida Industry. Tallahassee, Florida State Univ. Studies 36, 1962.

Greenhut, M. L., and H. Ohta. Theory of Spatial Pricing and Market Areas. Durham, Duke Univ. Press, 1975.

Greenhut, M. L., and Tate Whitman, eds. Essays in Southern Economic Development. Chapel Hill, Univ. of North Carolina Press, 1964.

Gross, Ermest, and H. S. Chang. "Changes in Elasticities of Interstate Migration: Implications of Alternative Functional Forms," J. Reg. Sci. 23 (May 1983), pp. 223-232.

Hale, Carl W. "Shift-Share Analysis as Descriptive Tool in Regional Analysis," Miss. Valley J. of Bus. \& Econ. 6, pp. 352-364.

Hale, Carl W. "Industrial Structure and Spatial Inputs and Outputs in the American Economy," Rev. Reg. Studies. 3 (Spring 1973), pp. 1-12.

Hamilton, C. Horace. Rural-Urban Migration in North Carolina, 1920 and 1950. Agri. Exp. Sta. Bull. No. 295, N.C. State College, Raleigh, (Feb. 1934).

Hamiton, C. Horace. "Rural-Urban Migration in the Tennessee Valley Between 1920 and 1930." Social Forces. 13 (Oct. 1934)

Hammond, Henry. South Carolina-Resources and Population. Institutions and Industries. Charleston, Walker, Evans \& Cogswell, 1883.

Hanna, Frank A. "Contribution of Manufacturing Wages to Regional Differences in Per Capita Income," Rev. Econ \& Stat. 36 (August 1954),

Hanna, Frank A. "State Per Capita Income Components," Rev. Econ \& Stat. 38 (Nov. 1956),

Hansen, Niles M. "A Growth Center Strategy for the U.S." Rev. Reg. Studies. 1 (Winter 1971), pp. 161-174.

Hansen, Niles M. Growth Centers in Regional Economic Development. New York, Free Press, 1972.

Hansen, Niles M. "The New International Division of Labor and Manufacturing Decentralization in the U.S." Rev. Reg. Studies. 9 (Winter 1079), pp. 1-11.

Hansen, Niles M. Public Policy and Regional Economic Development. Cambridge, Ballinger Publishing, 1974.

Harris, Curtis C., and Mehrzad Nadji. "The Spatial Content of the Arrow-Debreu General Equilibrium System,"J. Reg. Sci. 25 (Feb., 1985), pp. 1-10.

Harrison, Robert W. "Land Improvement v8. Land Settlement for the Southeast," Southern Econ. J. 12 (1945), pp. 23-38.

Haworth, C. T., and D. W. Rasmussen. "Determinants of Metropolitan Cost of Living Variations," Southern Econ. J. 44 (1978), pp. 183-192.

Heath, Milton S. "The Rate Structure." Law \& Contemporary Problems. 12 (Summer 1947), pp. 405-415.

Heath, Milton S. "The Uniform Class Rate Decision and Its Implications for Southern Economic Development," Southern Econ. J. 13 (Jan. 1946), pp. 213-137.

Heberle, Rudolf. "Regionalism: Some Critical Observations," Social Forces. XXI (1943), pp. 280-286.

Heer, C. Incomes and Wages in the South. Chapel Hill, Univ. of North Carolina Press, 1930.

Herring, Harriet L. Southern Resources for Industrial Development, Monograph 2, Southern Assoc. of Science \& Industry, Richmond, 1948.

Herzog, Henry W., Jr., and Richard J. Olsen. "Shift and Share Projections Revisited," J. Reg. Sci 17 (1977), pp. 441-454.

Hili, Lewis E. "Rates of Return on Municipal Subsidies to Industry: Comment," Southern Econ. J. XXX (April
1964), pp. 358-359.

Hite, James C. and Ellen J. Hall. "The Reactionary Evolution of Economic Thought in Antebellum Virginia," Va. Mag. Hist. Biog, 80 (Oct. 1972), pp. 476-488.

Hite, James C., and Eugene A. Laurent. Environmental Planning: An Economic Analysis. New York, Praeger, 1972.

Honea, R. B. "The Southeast's Energy Prospects: A Realistic Appraisal," Rev. Reg. Studies. 11 (Spring 1981), pp. 74-87.

Hoover, Calvin B. and B. U. Ratchford. Economic Resources and Policies of the South. New York, Macmillan, 1951.

Hopkins, Ernest J. "Mississippi's BAWI Plan, An Experiment in Subsidization," Atlanta, Federal Reeerve Bank of Atlanta, 1944.

Horiba, Y., and R. C. Kirkpatrick. "Factor Endowments, Factor Proportions, and the Allocative Efficiency of U.S. Interregional Trade." Rev. Econ. \& Stat. 63 (1981), pp. 178-187.

Horiba, Y. and R. C. Kirkpatrick. "U.S. North-South Labor Migration and Trade," J. Reg. Sci. 23 (Feb. 1983), pp. 93-103.

Isard, Walter. "A Neglected Cycle: The TraneportBuilding Cycle," Rev. Econ. \& Stat. 24 (Nov. 1942).

Isard, Walter. "Discussion on Interregional Variations in Economic Fluctuations," Papers \& Proc. of Amer. Econ. Assoc. 39 (May 1949).

Isard, Walter. "Interregional and Regional Input-Output Analysis: A Model of a Space Economy," Rev. Econ. \& Stat. 33 (Nov. 1951).

Isard, Walter, Methods of Regional Analysis, Cambridge, MIT Press, 1960.

Isard, Walter. "Regional Science, the Concept of Region and Regional Structure," Papers \& Proc. Reg. Sci. Assoc. 2 (1956).

Ireland, Tim C., and Ronald L. Moomaw. "The Competitive Effect in Shift-Share Analysis: A Will of the Wiep?" Rev. Reg. Studies. 11 (Winter 1981), pp. 33-49.

Jefferson, Thomas. Notes on the State of Virginia. (Originally published in 1787). Reprint in Thomas Jefferson-Writings. New York, The Library of America, 1984.

Jocher, Katherine, Guy B. Johnson, George L. Simpson and Rupert B. Vance, eds. Folk, Region and Society. Chapel Hill, Univ. of North Carolina Press, 1964.

Joubert, William H. Southern Freight Rates in Transition. Gainesville, Univ. of Florida Press, 1949.

Katz, Joseph L. "The Relationship Between Type I and Type II Income Multipliers in an Input-Output Model," Int. Reg. Sci. Rev. 5 (1980), pp. 51-56.

Kau, James B., and C. F. Lee. "Capital Land Substitution and Urban Land Use,"J. Reg. Sci. 16 (1976), pp. 83-92.

Kau, James B., and Linda L. Johnson. "Regional Science Programs: A Ranking Based on Publication Performance," J. Reg. Sci. 23 (May 1983), pp. 177-186.

Kettell, Thomas P. Southern Wealth and Northern Profits (Originally published in 1860), Reprinted by Univ. of Alabama Press, University, Ala., 1965.

Key, V. O., Jr., with Alexander Heard. Southern Politics in State and Nation. New York, Alfred A. Knopf, 1950.

Kline, H. B. "Freight Rates, The Interregional Tariff Issue," Papers of the Inst. of Research and Training in the Social Sciences. No. 2. Nashville, Vanderbilt Univ., April 1942.

Kraus, Michael. The Writing of American History. Norman, Univ. of Oklahoma Press, 1953.

Lancaster, John L. County Income Estimates for Seven Southeastern States. Charlottesville, Bur. of Pop. \& Econ. Research, Univ. of Virginia, 1952.

Latham, William R., III. "Needless Complexity in the Identification of Industrial Complexes,"J. Reg. Sci. 16 
(1976), pp. 45-55.

Latham, William R., III. The Measurement of Spatial Association," Rev. Reg. Studies. 7 (Winter 1977), pp. 1-13.

Lester, Richard A. "Diversity in North-South Wage Differentials and in Wage Rates within the South," Southern Econ. J. 12 (Jan. 1946), pp. 238-262.

Lester, Richard A. "Effectiveness of Factory Labor: South-North Comparisons." J. Pol Econ. 54 (Feb. 1946), pp. 60-75.

Lester, Richard A. "Trends in Southern Wage Differentials since 1890." Southern Econ. J. 11 (April 1945), pp. 314-344.

Lester, Richard A. "Southern Wage Differentials: Development, Analysis and Implications," Southern Econ. J. 13 (April 1947), pp. 386-394.

Lepawsky, Albert. State Planning and Economic Development in the South. Washington, Committee of the South, National Planning Assoc., Report No. 4, 1949.

Losch, A. "The Nature of Economic Regions," Southern Econ. J. 5 (1938), pp.

Lowry, 'Robert E. "Municipal Subsidies to Industry in Tennessee," Southern Econ. J. 7 (Jan. 1941), pp. 317-329.

Luisa, Peter C., and B. L. Dillman. "An Entrophy Analysis of Areal Concentration of Manufacturing Plants," Rev. Reg. Studies. 8 (Fall, 1978), pp. 1-9.

Maddox, James G. "Private and Social Costs of the Movement of People Out of Agriculture," Amer. Econ. Rev. 50 (May 1960), pp. 392-402.

Maddox, James G., E. E. Liebhafsky, Vivian W. Henderson and Herbert M. Hamlin. The Advancing South. New York. The Twentieth Century Fund, 1967.

Manuel, David P. "Higher Energy Prices and Resource Endowments in an Export Base Model Context," Rev. Reg. Studies. 12 (Winter 1982), pp. 32-41.

Markham, Jesse W. "Some Comments upon the NorthSouth Differential," Southern Econ. J. 16 (Jan. 1950), pp. 279-283.

Martin, James W. Conference on the Measurement of County Income: A Report of Three Years of Work. Lexington, Bur. of Bus. Research, Univ. of Kentucky, 1952.

Martin, Randolph C. "An Empirical Inquiry into the Effectiveness of the Growth Center Approach to Regional Economic Development," Rev. Reg. Studies. 8 (Winter 1978), pp. 1-19.

McElveen Jackson V., and Kenneth L. Bachman. Low Production Farms. Washington, U.S. Dept. of Agric., Agric. Info. Bull. No. 108, 1953.

McFerrin, John B. "Resources for Financing Industry in the South," Southern Econ. J. 14 (July 1947), pp. 46-61.

McGee, L. Randolph. Income and Employment in the Southeast-A Study in Cyclical Behavior. Lexington, Univ. of Kentucky Press, 1967.

McKinney, David. Income Payments to Mississippians. University, Bur. of Bus. Research, Univ. of Mississippi, 1952.

McKinney, John C. and Edgar T. Thompson, eds. The

South in Continuity and Change. Durham, Duke Univ. Press, 1965.

McLaughlin, Glenn E. and Stefan Robock. Why Industry Moves South: A Study of Factors Influencing the Recent Location of Manufacturing Plants in the South. Washington, Committee of the South, National Planning Assoc. Report No. 3, 1949.

Meyer, J. R. "Regional Economics: A Survey," Amer. Econ. Rev. 53 (1963), pp. 19-44.

Miernyk, William H. "Long-Range Forecasting with a Regional Input-Output Model," Western Econ. J. 6 (1968), pp. 165-176.
Miernyk, William H. Simulating Regional Economic Development. Lexington, Mass., Heath Lexington, 1970.

Miernyk, William H. "The Realism and Relevance of Regional Science," Rev. Reg. Studies. 6 (Winter, 1976), pp. $1-10$.

Miller, Stephen E., and Mark S. Henry. "Basic and Nonbasic Employment Linkages, Rev. Reg. Studies. 9 (Spring 1979), pp. 80-88.

Mitchell, Broadus, and George S. Mitchell. The Industrial Revolution in the South. Baltimore, The Johns Hopkins Press, 1930.

Moes, John E. Local Subsidies for Industry. Chapel Hill, Univ. of North Carolina Press, 1962.

Moore, John R. ed. The Economic Impact of TVA. Knoxville, Univ. of Tenn. Press. 1967.

Morgan, William E., and Merlin M. Hackbart. "An Analysis of State and Local Industrial Tax Exemption Programs," Southern Econ. J. 41 (Oct. 1974), pp. 200-150.

Moriarty, B. "The Distributed Lag Between Metropolitian Area Employment and Population Growth," J. Reg. Sci. 16 (May 1976), pp. 195-212.

Moroney, J. R. "Natural Resource Endowments and Comparative Advantage," J. Reg. Sci. 15 (1975), pp. $139-150$.

Moroney, J. R., and James M. Walker. "A Regional Test of the Heckscher-Ohlin Hypothesis," J. Pol. Econ. Dec. 1966.

Mulkey, David, and B. Dillman. "Locational Effects of State and Local Industrial Development Subsidies," Growth \& Change. 7 (April 1976), pp. 37-

Myers, Will S., John L. Johnson, and James W. Martin. Kentucky Income Payments by Counties, 1939, 1947, 1950, and 1951. Lexington, Bur. of Bus. Research, Univ. of Kentucky, Feb. 1953.

Myrdal, G. An American Dilemma. New York, Harper and Bros., 1944.

Needleman, L., ed. Regional Analysis. Harmondsworth, U. K., Penguin Books, 1968.

Nelson, Lowry, Rural Sociology. Second Ed. New York, American Book Co., 1955.

Nicholls, William H. "The Effects of Industrial Development on Tennessee Valley Agriculture," J. Farm. Econ. 38 (1956), pp. 1636-1649.

Nicholls, William H. "Human Resources and Industrial Development in the Upper East Tennessee Valley, 1900-1950," Quart. J. Econ. 71 (1957), pp. 289-316.

Nicholls, William H. "Some Foundations of Economic Development in the Upper East Tennessee Valley, 1850-1900,: J. Pol. Econ. 64 (1956), pp. 277-302; 400-415.

Nicholls, William H. Southern Tradition and Regional Progress. Chapel Hill, Univ. of North Carolina Press, 1960.

Odum, H. W. American Masters of Social Science. New York, Henry Holt, 1927.

Odum, H. W. Southern Regions of the U.S. Chapel Hill, Univ. of North Carolina Press, 1936.

Odum, H. W. "The Promise of Regionalism," in Regionalism in America, ed. by M. Jensen. Madison, Univ. of Wisconsin Press, 1952.

Odum, H. W. and Katherine Jocker. In Search of Regional Balance of America. Chapel Hill, Univ. of North Carolina Press, 1945.

Odum, H. W. and H. E. Moore. American Regionalism. New York, Henry Holt, 1938.

Olson, Mancur. "The South With Fall Again: The South as Leader and Laggard in Economic Growth," Southern J. Econ. 49-4 (April 1983), pp. 917-932.

Palmer, E. Z. "Sources and Distribution of Income in the South." Southern Econ. J. 2 (Jan, 1936), pp. 47-60. 
Phillips, Ulrich B. American Negro Slavery: A Survey of the Supply, Employment, and Control of Negro Labor as Determined by the Plantation Regime. Baton Rouge, LSU Press, 1918.

Phillips, Ulrich B. "The Central Theme of Southern History," Amer. His. Rev. XXXIV (1928), pp. 30-43.

Phillips, U. B. Lif and Labor in the Old South. Boston, Little Brown, 1929.

Pfouts, R. W. "An Empirical Testing of the Economic Base Theory," J. Amer. Inst. Planners. 23-2 (1957).

Ransom, R. L., and R. Sutch. One Kind of Freedom: The Economic Consequences of Emancipation. New York, Cambridge Univ. Press, 1977.

Ratchford, B. U. "Public Debts in the South," Southern Econ. J. 2 (Jan. 1936), pp. 13-25.

Reed, John S. One South An Ethnic Approach to Regional Culture. Baton Rouge, LSU Press, 1982.

Richardson, Harry W. "The State of Regional Economics: A Survey Article," Int. Reg. Sci. Rev. 3 (Fall 1978), pp. 1-48.

Rinehart, James R. "Rates of Return on Municipal Subsidies to Industry," Southern Econ. J. XXIX (April 1963), pp. 297-306.

Rinehart, James R. "Rates of Return on Municipal Subsidies to Industry: Reply," Southern Econ. J. XXX (April 1964), pp. 359-361.

Robock, Stefan H. "Industrialization and Economic Progress in the South," Southern Econ, J. 20 (April 1954), pp. 314-315.

Robock, Stefan H. "Rural Industries and Agricultural Development," J. Farm Econ. 34 (Aug. 1952), pp. 346-360.

Robock, Stefan H., and John M. Peterson. "Fact and Fiction About Southern Labor," Harvard Business Rev. 22 (March-April, 1954), pp. 79-88.

Ruttan, Vernon W. "The Impact of Urban-Industrial Development on Agriculture in the Tennessee Valley," J. Farm Econ. (Feb. 1955)

Schaffer, William A. "Estimating Regional Input-Output Coefficients," Rev. Reg. Studies. 2 (Spring 1972), pp. 57-71.

Schaffer, William A., and Kong Chu. "Nonsurvey Techniques for Constructing Regional Interindustry Models." Reg. Sci. Assoc. Papers. 33 (1969), pp. 83-101.

Serow, William J. "The Role of Long Distance Migration in the Rural Renaissance, in Gentrification, and in the Growth of the Sunbelt," Rev. Reg. Studies. 10 (Fall 1980), pp. 23-31.

Serow, William J., Julia H. Martin, and Michael A. Spar. "An Analysis of Population Growth Rates Within Typological Categories of Small Southern Cities," Rev. Reg. Studies. 10 (Winter 1980), pp. 29-47.

Shapiro, G. "Myrdal's Definition of the South: A Methodological Note, Amer. Soc. Rev. 13 (Oct. 1948)

Spengler, J. J. "Population Problems of the South," Southern Econ. J. 3 (April 1937), pp. 393-410; 4 (July 1937), pp. 1-27; 5 (Oct. 1937), pp. 131-153.

Spengler, J. J. "Regional Differences and the Future of Manufacturing in America," Southern Econ.J. 7 (April 1949), pp. 475-493.

Smith, T. Lynn. "Farm Trade Centers in Louisiana, 1901 to 1931," LSU Agric. Expt. Sta. Bull. 234. Baton Rouge, 1933.

Snavely, Tipton R. "The Place of Education in the Developing Economic Structure of the South," Southern Econ. J. 13 (April 1947), pp. 404-415.

Snavely, Tipton R. "Economic Thought and Economic Policy in the South," Southern Econ. J. 1 (Oct. 1933), pp. 1-14.

Spreen, Thomas H., and W. David Mulkey. "The Lagged
Effect of Basic Employment Changes in a Regional Economy," Rev. Reg. Studies. 8 (Fall 1978), pp. 60-65.

Starnes, George T. and Frank T. deVyver. Labor in the Industrial South: A Survey of Wages and Living Conditions in Three Major Industries of the New In. dustrial South. University, Va., Univ. of Virginia Press, 1930.

Starnes, George T., William M. Wilkins, and Paul P. Wiseman. The Labor Force of Two Rural Industrial Plants. Bur. of Pop. \& Econ. Research Univ. of Virginia, Charlottesville, 1951.

Stepp, James M. "Southern Agriculture's Stake in Occupational Freedom," Southern Econ. J. (August 1946), pp. 45-52.

Stepp, James M. "Some Economic Aspects of Industrial Water Supply in the South," Water Resources and Economic Development in the South. Agric. Policy Inst., N.C. State Univ., Raleigh, API Series 16, August 1965 , pp. 25-41.

Stepp, James M. "Regional Scientists and Regional Identity," Rev. Reg. Studies. 5-2 (Fall, 1975), pp. 123-130.

Stepp, James M. "Rural Industrial Development in Four Southern States." memo. Washington. Committee of the South, National Planning Assoc., 1948.

Stepp, J. M. and J. S. Plaxico, The Labor Supply of a Rural Industry. Clemson, S.C. Agric. Exp. Sta. Bull. No. 376. 1948.

Street, James H. The New Revolution in the Cotton Economy: Mechanization and its Consequences. Chapel Hill, Univ, of North Carolina Press, 1957.

Stocking, George W. Basing Point Pricing and Regional Development. Chapel Hill, Univ. of North Carolina Press, 1954.

Sufrin, C. S., A. W. Swinyard, and F. M. Stephenson. "The North-South Differential: A Different View." Southern Econ. J. 15 (Oct. 1948), pp. 184-190.

Tang, A. M. Economic Development in the Southern Piedmont, 1860-1950: Its Impact on Agriculture. Chapel Hill, Univ. of North Carolina Press, 1958.

Thompson, Arthur H. "The Contribution of Industrial Aid Bond Financing to Regional Economic Development," Rev. Reg. Studies. 1 (Winter 1971), pp. 185-210.

Thompson, Lorin A. "Appraisal of Alternative Methods of Estimating Local Area Income," in Regional Income. National Bureau of Econ. Research, Studies in Income and Wealth, Vol. 21. Princeton, Princeton Univ. Press, 1957.

Thompson, Wilbur R. "The Coefficient of Localization: An Appraisal," Southern Econ. J. 23 (Jan. 1957).

Tindall, George B. The Ethnic Southerners. Baton Rouge, LSU Press, 1976.

Tolley, George S., and H. W. Hjort. "Age-Mobility and Southern Farmer Skill-Looking Ahead for Area Development," J. Farm Econ. 45 (1963), pp. 31-46.

Twelve Southerners. I'll Take My Stand, The South and the Agrarian Tradition. New York, Harper and Row, 1930.

Vance, Rupert B. "The Geography of Distinction: The Nation and its Regions, 1790-1927," Social Forces. XVIII (1939), pp. 168-179.

Vance, Rupert B. Human Geography of the South. Chapel Hill, UNC Press, 1935.

Vance, Rupert B. "Sociological Implications of Southern Regionalism," J. South. His. XXVI (1960), pp. 44-56.

Vance, Rupert B., and Nicholas J. Demerath, eds. The Urban South. Chapel Hill, Univ. of North Carolina Press, 1954.

van Sickle, J. V. Planning for the South. Nashville, Vanderbilt Univ. Press, 1943.

van Sickle, J. V. "Public Works, Economic Stabilization and the Rural South," Papers of the Inst. of Research 
and Training in the Social Sciences. No. 2. Nashville, Vanderbilt Univ., January 1942.

van Sickle, J. V. "Regional Aspects of the Problem of Full Employment at Fair Wages," Southern Econ. J. 13 (1946), p. 37.

Vining, R. "Delimitation of Economic Areas: Statistical Conceptions in the Study of the Spatial Structure of an Economic System," J. Amer. Stat. Assoc. 48 (March 1943).

Vining, R. "Location of Industry and Regional Patterns of Business-Cycle Behavior," Econometrica. 14 (Jan. 1946).

Vining, R. "The Region as Concept in Business Cycle Analysis," Econometrica. 14 (July 1946).

Vining, R. "The Region as an Economic Entity and Certain
Variations to be Observed in the Study of Systems of Regions," Papers and Proc. of the Amer. Econ. Assoc. 39, May 1949.

Vining, R. On Appraising the Performance of an Economic System. Cambridge, Cambridge Univ. Press, 1984.

Walton, Gary M., and James F. Shepard, eds. Market Institutions and Economic Progress in the New South, 1865-1900. New York, Academic Press, 1981.

Weiss, Shirley J., and E. C. Gooding. "Estimation of Differential Employment Multipliers in a Small Regional Economy." Land Econ. 44 (1968), pp. 235-244.

Williams, B. O. "Occupational Mobility Among Farmers," S.C. Agric. Exp. Sta. Bull 296. Clemson, Clemson Agric. College, June 1934. 